\title{
THE EFFECT OF DISTRICT OWN-SOURCE REVENUE AND BALANCE FUNDS ON PUBLIC WELFARE BY CAPITAL EXPENDITURE AND ECONOMIC GROWTH AS AN INTERVENING VARIABLE IN SPECIAL DISTRICT OF YOGYAKARTA
}

\author{
Rudy Badrudin $^{1 *}$, Irawan Kuncorojati ${ }^{1}$ \\ ${ }^{1,2}$ YKPN School of Business Yogyakarta, Indonesia \\ *Corresponding author; Email: rudybadrudin.stieykpn@gmail.com
}

\begin{abstract}
The transfer funds from the central government which is not followed by own source revenues, causes the autonomous district too dependent on the central government funds. This study aims to determine the effect of own-source revenue and balance funds on public welfare by capital expenditure and economic growth as an intervening variable in Special District of Yogyakarta. The source of data is secondary data during 2006 to 2013 and using Partial Least Square to test hypotheses. The result showed that own-source revenue has not significant effect on capital expenditure but has significant effect on economic growth and public welfare; balance funds has significant effect on capital expenditure but has not significant effect on economic growth and public welfare; capital expenditure has significant effect on economic growth but has not significant effect on public welfare; and economic growth has not significant effect on public welfare.
\end{abstract}

Keywords: Regional budget, capital expenditure, growth, welfare.

\section{Introduction}

The implementation of regional autonomy to meet the goals of democratization and the public welfare, the balance of financial resources is a guarantee of the implementation of government affairs were delegated to the regions (Badrudin, 2011). When the area has the financial capacity is insufficient to finance government affairs, particularly the mandatory government affairs related to basic services, the central government can use instruments balanced fund to help the region in accordance with national priorities to be achieved (Setiaji \& Adi, 2007).

In general, the source of funding in the implementation of regional autonomy consists of budget revenue and other legitimate acceptance (Hirawan, 2007). The region that has potential as natural resources and human resources will generate huge revenue. Funding from the own-source revenue, a big plus with the form of balanced funds, general allocation fund, and special allocation fund from the central government, it will affect economic growth of the region. This indicates that the development in the area went smoothly because of the development budget is fulfilled (Badrudin, 2015).

Based on the description in the introduction, the study objectives were to be achieved is to test and analyze the effect of 1) own-source revenue on capital expenditures; 2) own-source revenue on economic growth; 3) own-source revenue on public welfare; 4) balance funds on capital expenditure; 5) balance funds on economic growth; 6) balance funds on public welfare; 7) capital expenditure on economic growth; 8) capital expenditure on public welfare; and 9) economic growth on public welfare in districts/city Special District of Yogyakarta.

\section{Literature Review}

According to Susanto and Badrudin (2016), fiscal decentralization with a number of strong government spending and will significantly impact on the low level of corruption. This happens because the legislation to support fiscal decentralization is very clear that there is no doubt the government apparatus to conduct government spending (Abdullah \& Asmara, 2007). According to Badrudin and Siregar (the national political 2015), forces to significantly increase the yield of fiscal decentralization as economic growth, the quality of government, and the provision of public goods. Instead, the subordination of the administration by appointing local politicians is not through with the elections it will lower results for fiscal decentralization. Thus, the Regional Representatives Council (DPRD) was instrumental in realizing the goal of regional development to improve the public welfare (Jensen \& Meckling, 1976).

The region that has adequate facilities and infrastructure will affect the level of productivity of society and will attract investors to invest in the region. The increase in revenue is expected to have a significant effect on capital expenditure. The increase 
in capital expenditure will be able to improve the quality of public services and will ultimately enhance the level of public participation on development (Badrudin, 2015). Research by Darwanto and Yustikasari (2006) showed that the own-source revenue has significant effect on capital expenditure. Based on these descriptions then compiled the research hypothesis as follows:

$H_{1}$ : The own-source revenue has positive significant effect on capital expenditure in the districts/city Special Region of Yogyakarta.

Research by Badrudin (2016) showed that the own-source revenue influences positively to economic growth in the region. It also supports the statement of National Planning Agency (Bappenas) which asserts that economic growth should be sensitive to the increase in economic growth (Badrudin \& Siregar, 2015). According to Setyawati and Hamzah (2007), the own-source revenue has positive and significant effect on economic growth. According to Nanik (2015), the own-source revenue influence on public welfare that measured by the Human Development Index (HDI). Based on these descriptions then compiled the research hypothesis as follows:

$H_{2}$ : The own-source revenue has positive significant effect on economic growth in the districts/city Special Region of Yogyakarta.

$H_{3}$ : The own-source revenue has positive significant effect on public welfare in the districts/city Special Region of Yogyakarta.

The balance funds to support the implementation of the authority of local governments to achieve improved services and public welfare According to Ferdian (2013), the balance funds a significant positive effect on regional spending. According to Azzumar and Handayani (2011), the balance funds not significant effect on economic growth. Research by Lugastoro and Ananda (2013) showed that contribute the balance funds have little influence in improving the HDI. Based on these descriptions then compiled the research hypothesis as follows:

$H_{4}$ : The balance funds have positive effect on capital expenditure in the districts/city Special Regi on of Yogyakarta.

$H_{5}$ : The balance funds have positive effect on economic growth in the districts/city Special Region of Yogyakarta.

$H_{6}$ : The balance funds have positive effect on public welfare in the districts/city Special Region of Yogyakarta.
Research by Mawarni and Abdullah (2013) showed that capital expenditure has not significant effect on economic growth. Research by Mirza (2012) showed that government-issued capital expenditure has significant positive effect on the HDI in Central Java province. Based on these descriptions then compiled the research hypothesis as follows:

$H_{7}$ : The capital expenditure has positive effect on public welfare in the districts/city Special Region of Yogyakarta.

According to Setyowati and Suparwati (2012), the economic growth has significant positive on public welfare. The increase in economic growth impact on improving of the public welfare, Based on these descriptions then compiled the research hypothesis as follows:

$H_{8}$ : The economic growth has positive effect on public welfare in the districts/city Special Region of Yogyakarta.

\section{Research Method}

The population used in this study was all local government in districts or city Special Region of Yogyakarta with a population of four districts and one city in the period 2006 to 2013. The sample in this study is Kulon Progo, Bantul, Gunung Kidul, Sleman, and Yogyakarta City which did not undergo pansion area since regional autonomy implemented as of 2001, so that the originality of the region can be maintained. The research model is Partial Least Square (PLS) follows the pattern of structural equation modeling (SEM) based variance is WarpPLS that can simultaneously perform testing at the measurement and structural model. Construction path diagram can be seen in Figure 1.

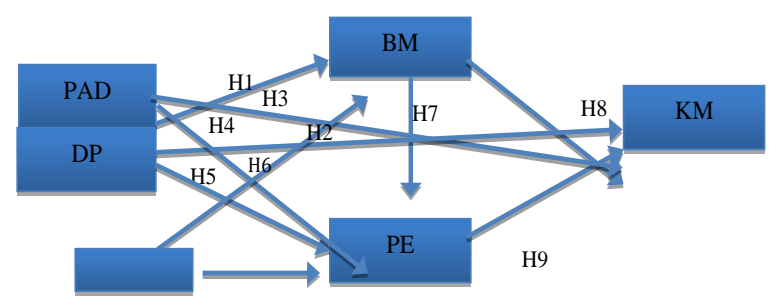

Figure 1

Research Model Line

Information:

PAD: own-source revenue

DP : balance fund

BM : capital expenditure

$\mathrm{PE}$ : economic growth

$\mathrm{KM}$ : public welfare

: Observation variables

: The relationship between the variables 
Table 1

Descriptive Statistical of Variables in Districts/City Special Region of Yogyakarta

\begin{tabular}{cccccc}
\hline $\begin{array}{c}\text { Descriptive } \\
\text { Statistical }\end{array}$ & $\begin{array}{c}\text { Own-Source Revenue } \\
\text { (Rp million) }\end{array}$ & $\begin{array}{c}\text { Balance Fund } \\
\text { (Rp million) }\end{array}$ & $\begin{array}{c}\text { Capital Expenditure } \\
\text { (Rp million) }\end{array}$ & $\begin{array}{c}\text { Economic } \\
\text { Growth (\%) }\end{array}$ & Public Welfare \\
\hline Mean & 124,043 & 627,578 & 112,024 & 4.66 & 75.19 \\
Minimum & 28,878 & 361,777 & 40,810 & 2.02 & 69.44 \\
Maximum & 449,270 & 992,782 & 302,760 & 5.76 & 80.51 \\
\hline
\end{tabular}

Source: Secondary data, processed.

Table 2

Research Hypothesis Testing Results

\begin{tabular}{|c|c|c|c|c|c|}
\hline $\begin{array}{c}\text { Relationship Between } \\
\text { Variables }\end{array}$ & Coefficient & $P$-Value & Prediction & Finding & Conclusion \\
\hline $\mathrm{PAD} \rightarrow \mathrm{BM}$ & -0.18 & 0.32 & + & - & Rejected \\
\hline $\mathrm{PAD} \rightarrow \mathrm{PE}$ & 0.62 & $<0.01$ & + & + & Accepted \\
\hline $\mathrm{PAD} \rightarrow \mathrm{KM}$ & 1.06 & $<0.01$ & + & + & Accepted \\
\hline $\mathrm{DP} \rightarrow \mathrm{BM}$ & 0.52 & $<0.01$ & + & + & Accepted \\
\hline $\mathrm{DP} \rightarrow \mathrm{PE}$ & -0.04 & 0.41 & + & - & Rejected \\
\hline $\mathrm{DP} \rightarrow \mathrm{KM}$ & 0.11 & 0.35 & + & + & Accepted \\
\hline $\mathrm{BM} \rightarrow \mathrm{PE}$ & 0.37 & 0.01 & + & + & Rejected \\
\hline $\mathrm{BM} \rightarrow \mathrm{KM}$ & 0.00 & 0.50 & + & + & Rejected \\
\hline $\mathrm{PE} \rightarrow \mathrm{KM}$ & -0.15 & 0.24 & + & - & Rejected \\
\hline
\end{tabular}

Source: Figure 2 (data processed).

\section{Results and Discussions}

Descriptive statistical analysis results are shown in Table 1. Based on Table 1 seemed average of ownsource revenue for all districts/city per 8 years amounted to $\mathrm{Rp} 124,043$ million. The own-source revenue lowest in Gunung Kidul in 2007 amounted to $\mathrm{Rp}$ 28,878 million and highest in Sleman in 2013 amounted to Rp 449,270 million. The own-source revenue describes the ability of the districts/city in Special Region of Yogyakarta to achieve the public welfare. The average of balanced fund for all districts/ city per 8 years amounted to $\operatorname{Rp} 627,578$ million. The balance fund lowest in Yogyakarta City in 2006 amounted to $\mathrm{Rp} 361,777$ million and highest in Sleman in 2013 amounted to Rp 992,782 million. The higher the balance funds illustrates the degree of dependency on funds transfers from the central government is getting higher and shows that the lower the degree of independence. Based on Table 1 seemed average of capital expenditures for all districts/city per 8 years amounted to Rp 112,023 million. The capital expenditure lowest in Kulon Progo in 2009 amounted to Rp 40,810 million and highest in Bantul in 2008 amounted to Rp 302,760 million. The average of economic growth for all districts/city per 8 years amounted to $4.66 \%$. The economic growth lowest in Bantul in 2006 amounted to $2.02 \%$ and highest in Yogyakarta City in 2012 amounted to 5.76\%. The average of public welfare for all districts/city per 8 years amounted to 75.19 . The public welfare lowest in Gunung Kidul in 2006 amounted to 69.44 and prosperity occurred in Yogyakarta City in 2013 amounted to 80.51 .

This study does not test models outer covering validity and reliability test because the data used in this study was measured data. Goodness of Fit Inner Model on PLS analysis using sizes Stone-Geisser QSquare test. The size of this form of $Q$-Square predictive relevance is calculated based on the value of $R^{2}$ each endogenous variable, capital expenditure $\left(R_{\mathrm{BM}}{ }^{2}\right)$ amounted to 0.246 ; economic growth $\left(R_{\mathrm{PE}}^{2}\right)$ amounted to 0.614 ; and public welfare $\left(R_{\mathrm{KM}}{ }^{2}\right)$ amounted to 0.778 . Thus, the value of the $Q$-Square predictive relevance for:

$$
\begin{aligned}
Q^{2} & =1-\left(1-R_{\mathrm{BM}}^{2}\right)\left(1-R_{\mathrm{PE}}{ }^{2}\right)\left(1-R_{\mathrm{KM}}{ }^{2}\right) \\
& =1-(1-0.246)(1-0.614)(1-0.778) \\
& =1-(0.754)(0,386)(0,222) \\
& =1-0.065 \\
& =0.935
\end{aligned}
$$

Based on these calculations, the value of the $Q$ Square predictive relevance of $93.5 \%$, so the model is said to have a strong predictive value for variables in the model that includes own-source revenue, balance funds, economic growth, and public welfare are able to explain the variable at $93.5 \%$, while the remaining $6.5 \%$ is a variation other variables outside the model. Figures and table hypothesis testing research results are presented in Figure 2 and Table 2. 


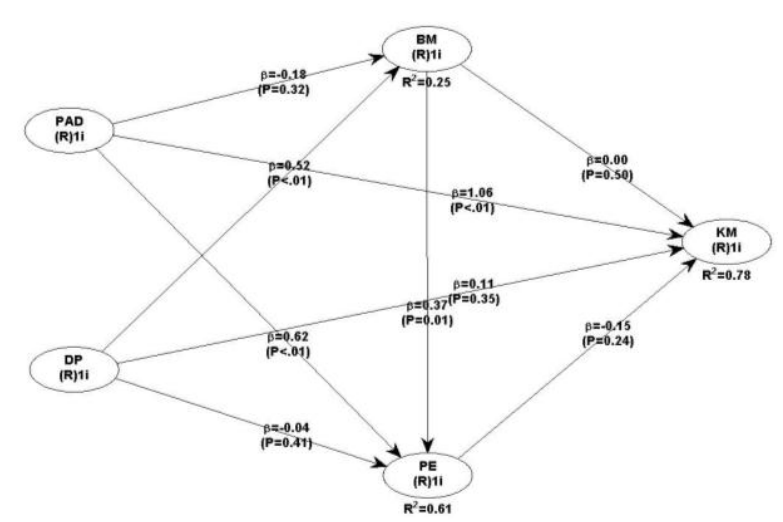

Figure 2.

Results of the PLS Output Hypothesis Testing

Based on the results of hypothesis testing known that own-source revenue has significant negative effect on capital expenditure in the districts/city Special Region of Yogyakarta, It can be seen from the coefficient $(\beta)$ of -0.18 , which indicates that ownsource revenue has negative effect on capital expenditure. The significance level of 0.32 is greater than the significance level $5 \%$. The test results showed that $H_{l}$ is rejected. The local government has not been able to allocate revenue to capital expenditure effectively. Viewe from the expenditure side the largest expenditure component used for personel expenditure. Components of expenditures for goods and services expenditures ranged between 12-29 percent, while expenditure on capital expenditure ranges between 10-15 percent. This is the phenomenon of flypaper effect (Maimunah, 2006).

Based on the results of hypothesis testing known that own-source revenue has significant positive effect on economic growth in the districts/city Special Region of Yogyakarta, It can be seen from the coefficient $(\beta)$ of 0.62 , which indicates that own-source revenue has positive effect on economic growth. The significance level of $<0.01$ less than that significance level $5 \%$. The test results showed that the $H_{2}$ is accepted. The economic growth in Special Region of Yogyakarta is an exclusive economic growth. It can be seen from the development that shows the Gini index of income inequality that occurred in Special Region of Yogyakarta. The Gini index of Special Region of Yogyakarta has a tendency to increase from 0.366 in 2007 to 0.439 in 2013. By comparing the rate of economic growth and development of the Gini index shows that the rise in per capita income growth accompanied by rising income inequality.

Based on the results of hypothesis testing known that own-source revenue has significant positive effect on public welfare in the districts/city Special Region of Yogyakarta, It can be seen from the coefficient $(\beta)$ 1.06 , which indicates own-source revenue has positive effect on public welfare. The significance level of $<0.01$ less than the significance level $(5 \%)$. The test results indicate that the $H_{3}$ is accepted. The quality of life in Special Region of Yogyakarta which is reflected in the HDI tends to increase. The HDI figures quite high and shows the development of the increase. In 2013, the HDI is (76.75) that are ranks fourth after DKI Jakarta (78.33), North Sulawesi (76.95) and Riau (76.90).

Based on the results of hypothesis testing known that balanced fund has significant positive effect on capital expenditure in the districts/city Special Region of Yogyakarta. It can be seen from the coefficient $(\beta)$ 0.52 , which indicates that balanced fund has positive effect on capital expenditure. The significance level of $<0.01$ less than the significance level $5 \%$, the test results indicate that the $H_{4}$ is accepted. The local government can allocate the balance fund of central government in the capital expenditure effectively. The higher proportion of balanced fund in the budget structures of the district/ city shows that the greater the degree of dependency on funds transfers from the central government and shows that the lower the degree of independence. The significant balance funds on capital expenditure are also influenced by the indication of the phenomenon of flypaper (Maimunah, 2006).

Based on the results of hypothesis testing known that balanced fund has significant negative effect on economic growth in the districts/city Special Region of Yogyakarta. It can be seen from the coefficient $(\beta)$ of -0.04 , which indicates that balanced funds have negatively affected on economic growth. The significance level of 0.41 is greater than the significance level 5\%. The test results showed that $H_{5}$ is rejected. View from the expenditure side, the largest expenditure component used for personel expenditure. Component expenditure on goods and services ranging from $12-29 \%$ while capital expenditure ranged between $10-15 \%$, a high proportion of personel expenditure would reduce the proportion of capital expenditure in Special Region of Yogyakarta. The proportion of capital expenditures to build the infrastructure area is only about $10-15 \%$ less than optimal and less able to boost economic growth in Special Region of Yogyakarta. Flypaper phenomenon seen from the DAU obtained, so the impact on the allocation of balanced fund are not optimal. Exclusive economic growth occurred in Special Region of Yogyakarta seen from the Gini index has a tendency to increase from 0.366 in 2007 to 0.439 in 2013. That is the increase in per capita income growth accompanied by rising income inequality. 
Based on the results of testing the hypothesis in mind that balance fund has not significant positive effect on public welfare in the districts/city Special Region of Yogyakarta. It can be seen from the coefficient $(\beta)$ of 0.11 , which indicates that balanced fund has positive effect on public welfare. The significance level of 0.35 is greater than the significance level $5 \%$. The test results indicate that $H_{6}$ is rejected. The proportion of capital expenditures to build the infrastructure area is only about $10-15$ percent less than optimal and less boost economic growth in Special Region of Yogyakarta. The exclusive economic growth occurs because the portion of capital expenditure is relatively low. This indicates the phenomenon of flypaper in Special Region of Yogyakarta impact on the optimization of the balance funds (Maimunah, 2006).

Based on the results of testing the hypothesis in mind that capital expenditure has significant positive effect on economic growth in the districts/city Special Region of Yogyakarta, it can be seen from the coefficient $(\beta)$ of 0.37 , which indicates that capital expenditure has positive influence on economic growth. The significance level of 0.01 less than the significance level $5 \%$. The test results showed that the $\mathrm{H}_{7}$ is accepted. The local government is able to allocate capital expenditure effectively to regional economic growth. Utilization of expenditure allocated to productive things, for example for infrastructure development. However, economic growth is still going to be exclusive. This is shown by the Gini Index figures Special Region of Yogyakarta which has a tendency to increase from 0.366 in 2007 to 0.439 in 2013.

Based on the results of testing the hypothesis in mind that capital expenditure has not significant positive effect on public welfare in the districts/city Special Region of Yogyakarta, It can be seen from the coefficient $(\beta)$ of 0.00 , which indicates that capital expenditure has positive influence on public welfare. The significance level of 0.50 is greater than the significance level 5\%. The test results showed that the $H_{8}$ is rejected. The construction is expected to increase the rate of economic growth and ultimately improve the public welfare. The proportion of capital expenditures in districts/city Special Region of Yogyakarta is relatively low at around $10-15 \%$, less than optimal and less able to encourage improvement of public welfare in the districts/city Special Region of Yogyakarta.

Based on the results of hypothesis testing known that economic growth has not significant negative effect on public welfare in the districts/city Special Region of Yogyakarta, It can be seen from the coefficient $(\beta)-0.15$, which indicates that economic growth negatively affect public welfare. The significance level of 0.24 is greater than the specified significance level 5\%. The test results showed that the $\mathrm{H}_{9}$ is rejected. This can be seen from the development of the Gini index shows the income inequality that occurred in Special Region of Yogyakarta. The Gini index has a tendency to increase is from 0.366 in 2007 to 0.439 in 2013. That is, the increase is in per capita income growth accompanied by rising income inequality.

\section{Conclusion and Implication}

Based on the discussion, it was concluded in the study. First, own-source revenue can not affect capital expenditure. Local government can not allocate revenue on capital expenditures effectively. Second, own-source revenue can affect economic growth. This is demonstrated by the increasing rate of economic growth every year. Third, own-source revenue can affect public welfare. This is demonstrated by the increased number of HDI which explains the increase in public welfare. Fourth, balance fund can affect capital expenditure. The local government can allocate the balanced fund of the central government in the capital expenditure effectively. Fifth, balanced funds can not affect economic growth. The proportion of capital expenditures to build the infrastructure area is only about $10-15$ percent less than optimal and less boost economic growth. Sixth, balanced fund can not affect public welfare. Lack of balance funds role on economic growth as an indication that the local government is not maximized in the area of financial management. Seventh, capital expenditures affect economic growth. The local government has allocated capital expenditure effectively to regional economic growth. Eighth, capital expenditure can not affect public welfare. The proportion of capital expenditures is relatively low. Ninth, economic growth can not affect public welfare. This can be seen from the development of the Gini index shows the income inequality. The Gini index has a tendency to increase from 0.366 in 2007 to 0.439 in 2013.

The data of capital expenditure in this study is a capital expenditure in the sense of quantity. Therefore, the authors have limitations to unravel how the allocation of capital expenditure in influencing inclusive growth. Those meaning economic growth in this research more towards exclusive rather than inclusive. Subsequent research in order to use the capital expenditure data in quantity and qualitative sense, this is important in measuring the success of the quality of economic development. This study shows the phenomenon of flypaper in the districts/city Special Region of Yogyakarta. Therefore, further research ne- 
eds to consider the analysis of the phenomenon of flypaper that influences the allocation of sources of local revenue for local development activities in order to achieve public welfare in the districts/city of Special Region of Yogyakarta

\section{References}

Abdullah, S. \& Asmara, J. A. (2007). Perilaku oportunistik legislatif dalam penganggaran daerah: Bukti empiris atas aplikasi agency theory di sektor publik. Jurnal Riset Akuntansi Indonesia, 10(1),19-31.

Azzumar, M. R. \& Handayani, H. R. (2011). Pengaruh pendapatan asli daerah, dana perimbangan, investasi swasta, tenaga kerja terhadap partumbuhan ekonomi di era desentralisasi fiskal tahun 2005-2009: Skasus kabupaten/kota provinsi Jawa Tengah. Jurnal Ekonomi \& Bisnis, 9(3), 161-182.

Badrudin, R. (2011). Effect of fiscal decentralization on capital expenditure, growth, and welfare. Economic Journal of Emerging Market, 3(3), 211-223.

(2015). Evaluation of the specific allocation fund for Indonesian society welfare. International Journal of Applied Business and Economic Research, 13(7), 5607-5624. Retrieved from http: //www.serialsjo urnals.com/serialjournalmanager/pdf/1457769178.pdf.

Badrudin, R. (2016). The model of inclusive development in Bali province. International Journal of Business and Commerce, 6(1), 09-22. Retrieved from http://www.ijbcnet.com/6-1/ IJBC-16-6103.p df.

Badrudin, R. \& Siregar, B. (2015). The evaluation of the implementation of regional autonomy in Indonesia. Economic Journal of Emerging Markets, 7(1), 1-11. Retrieved from http://journal.uii.ac. id/ index.php/JEP/article/view/4257.

Darwanto, D. \& Yustikasari, Y. (2007). Prosiding simposium nasional akuntansi 2007: Simposium nasional akuntansi X. Yogyakarta: Magister Sains Ilmu-ilmu Ekonomi, Manajemen, Akuntansi UGM.

Ferdian, Y. (2013). Pengaruh pendapatan asli daerah, dana perimbangan, dan lain-lain pendapatan yang sah terhadap belanja daerah. Jurnal Akuntansi, 1(2), 78-91.

Hirawan, S. B. (2007). Desentralisasi fiskal sebagai suatu upaya meningkatkan penyediaan layanan publik (bagi orang miskin) di Indonesia. Jurnal Ekonomi Pembangunan, 8(1), 21-34.
Jensen, M. C. \& Meckling, W. H. (1976). Theory of the firm: Managerial behavior, agency costs and ownership structure. Journal of Financial Economics, 3(4), 305-360. Retrieved from http:// papers.com.

Lugastoro, D. P. \& Ananda, C. F. (2013). Analisis pengaruh PAD dan dana perimbangan terhadap indeks pembangunan manusia kabupaten/kota di Jawa Timur. Jurnal Ilmiah Mahasiswa, 1(2), 89-101.

Maimunah, M. (2006). Prosiding simposium nasional akuntansi 2007: Simposium nasional akuntansi IX. Yogyakarta: Magister sains ilmu-ilmu ekonomi, manajemen, akuntansi UGM.

Mawarni, D. \& Abdullah, S. (2013). Pengaruh pendapatan asli daerah dan dana alokasi umum terhadap belanja modal serta dampaknya terhadap pertumbuhan ekonomi daerah: studi pada kabupaten dan kota di Aceh. Jurnal Akuntansi, 4(3), 164-181.

Mirza, D. S. (2012). Pengaruh kemiskinan, pertumbuhan ekonomi, dan belanja modal terhadap indeks pembangunan manusia di Jawa Tengah tahun 2006-2009. Economics Development Analysis Journal, 1(2), 79-91.

Nanik, N. (2015). Pengaruh pendapatan asli daerah, dana bagi hasil, dana alokasi umum, dan dana alokasi khusus terhadap indeks pembangunan manusia kota/kabupaten di provinsi di Yogyakarta. Program Doktor FEB UGM, Yogyakarta.

Setiaji, W. \& Adi, P. H. (2007). Prosiding simposium nasional akuntansi 2007: Simposium nasional akuntansi X. Yogyakarta: Magister sains ilmuilmu ekonomi, manajemen, akuntansi UGM.

Setyawati, A. \& Hamzah A. (2007). Analisis PAD, DAU, DAK, dan belanja pembangunan terhadap pertumbuhan ekonomi, pengangguran, dan kemiskinan: Pendekatan analisis jalur. Jurnal Akuntan dan Keuangan Indonesia, 4(2), 211-228.

Setyowati, L. \& Suparwati, Y. K. (2012). Pengaruh pertumbuhan ekonomi, DAU, DAK, PAD terhadap indeks pembangunan manusia dengan pengalokasian anggaran belanja modal sebagai variabel intervening: Studi empiris pada pemerintah kabupaten dan kota se-Jawa Tengah. Prestasi, 9(1), 24-46.

Susanto, D. \& Badrudin, R. (2016). Budgeting politic for supporting competitive industry sector. International Journal of Business and Commerce, 5(6), 49-64. Retrieved from http://www.ijbcnet. com /5-6/IJBC-16-5607.pdf. 